Jan P. Strumiłowski OCist ${ }^{1}$

Wyższe Seminarium Duchowne w Katowicach-Panewnikach

\title{
Epifanijne znaczenie konania Jezusa w Ogrójcu w świetle communicatio idiomatum
}

\section{Natura communicatio idiomatum}

Doktryna o współorzekaniu przymiotów ściśle wiąże się z doktryną o unii hipostatycznej ${ }^{2}$ sformułowanej na soborze chalcedońskim ${ }^{3}$, który był zwieńczeniem sporów chrystologicznych na temat zjednoczenia dwóch natur w jednej hipostazie. Orzeczenie chalcedońskie miało zabezpieczać prawdę o jedności osoby Chrystusa, w której zjednoczone są dwie natury. Jednakże nawet po soborze sformułowany dogmat prowadził do pytań na temat przypisywania konkretnych własności obu natur oraz możliwości wzajemnego o nich orzekania. W dużej mierze problematyczne

1 Jan Paweł Strumiłowski OCist - doktor teologii dogmatycznej, wykładowca Wyższego Seminarium Duchownego w Katowicach-Panewnikach. Zajmuje się teologią piękna, teologią trynitarną i chrystologią oraz teologiczną teorią poznania, zwłaszcza w aspekcie egzystencjalnymi estetycznym, a także jej relacjami z filozofią współczesną oraz naukami empirycznymi. E-mail: jancist@gmail.com.

2 Por. G. Strzelczyk, Communicatio idiomatum. Propozycja systematyzacji, „Śląskie Studia Historyczno-Teologiczne" 43 (2010) nr 2, s. 294.

3 Por. Sobór Chalcedoński, Definicja wiary, 11, w: Dokumenty Soborów Powszechnych: tekst grecki, łaciński, polski, t. 1, red. A. Baron, H. Pietras, tłum. T. Wnętrzak, Kraków 2005, s. 222-223. 
było cierpienie Chrystusa w kontekście niecierpiętliwości natury boskiej. Innymi słowy powstało pytanie, w jaki sposób każda z natur może przekazywać swoje cechy konkretnej hipostazie wcielonego Słowa ${ }^{4}$. Ojcowie, starając się rozwikłać ten problem, stwierdzili, że przymioty i właściwości, jak np. cierpienie, śmiertelność, niecierpiętliwość czy wieczność, są przynależne naturze, lecz konkretyzują się w hipostazie. Dlatego też nie można powiedzieć, że cierpiała natura boska Chrystusa, ale cierpiała Jego hipostaza w ludzkiej naturze ${ }^{5}$. Wymiana przymiotów nie implikuje zatem możliwości przypisania jednej naturze cech natury drugiej. Tymczasem mówiąc o hipostazie, winniśmy orzekać cechy obu natur ${ }^{6}$ - zatem możemy powiedzieć, że Chrystus cierpiał w ludzkiej naturze, a jednocześnie możemy powiedzieć, że Chrystus jest śmiertelny co do człowieczeństwa i nieśmiertelny co do Bóstwa7.

Znaczenie zjednoczenia i współorzekania jest jednak bardziej złożone, niż mogłoby wynikać z powyższych rozważań. Jedność hipostatyczna, w której natury połączyły się „,bez zmieszania, bez zmiany, bez podzielenia i bez rozłączenia"s, nie niszcząc różnicy natur i zachowując cechy właściwe każdej z nich, oznaczało, że w zjednoczeniu Słowo przyjęło na siebie wszystko, co ludzkie, z wyjątkiem grzechu'.

Na kanwie tak sformułowanej nauki o hipostatycznym zjednoczeniu natur ojcowie, zwalczając herezje agnoetów, jasno stwierdzali, że Chrystus prawdziwie doświadczał wszystkich stanów właściwych ludzkiej naturze, a więc również strachu i niewiedzy. Zaznaczali jednocześnie, zgodnie z Tradycją, że owe stany należy odnosić do poszczególnych natur. Niektóre cechy jednakże są właściwe obu naturom, co domagało się dopowiedzenia. W kwestii więc na przykład wiedzy Jezusa należało

4 Por. J. J. Pelikan, Duch wschodniego chrześcijaństwa (600-1700), tłum. M. Piątek, Kraków 2009, s. 101.

5 Por. J. J. Pelikan, Duch wschodniego chrześcijaństwa..., dz. cyt., s. 101.

6 Por. J. J. Pelikan, Duch wschodniego chrześcijaństwa..., dz.cyt., s. 101-102.

7 Warto zauważyć, że dokładnie taką strukturę posiada wyznanie chalcedońskie. Zob. Sobór Chalcedoński, Definicja wiary, dz. cyt., 11.

8 Sobór Chalcedoński, Definicja wiary, dz.cyt., 11.

9 Por. J. J. Pelikan, Duch wschodniego chrześcijaństwa..., dz. cyt., s. 101; Sobór Chalcedoński, Definicja wiary, dz.cyt., 11. 
stwierdzić, że posiadał On podwójną wiedzę, dotyczącą mądrości boskiej, którą posiadał w pełni, i mądrości ludzkiej, którą nabywał ${ }^{10}$.

Niemniej jednak na podstawie owego zjednoczenia (chociaż dalsze spory dowodziły, że w Chrystusie mamy do czynienia z dwiema wolami i dwoma działaniami, gdyż zarówno działanie, jak i wola przynależą naturze, a nie hipostazie ${ }^{11}$ ), cechującego się absolutną zgodnością związaną z zapośredniczeniem w jednym podmiocie (jednej hipostazie), możemy mówić nie tylko o czynie boskim z jednej i czynie ludzkim z drugiej strony, ale też o czynie Chrystusa, co w pełni wyraża prawdę o synergii dwóch natur ${ }^{12}$. W ten sposób, opierając się na nauce o współorzekaniu przymiotów, możemy powiedzieć, że Chrystus dokonywał czynów boskich na sposób ludzki ${ }^{13}$. Jeszcze dosadniej i precyzyjniej mówiąc, możemy stwierdzić, że

między jego [Chrystusa] Bóstwem i człowieczeństwem nie było żadnego, nawet najdrobniejszego rozłamu czy pęknięcia, co nie znaczy, że jego ludzka natura stała się naturą Boską. Doniosłość zjednoczenia, o którym mowa, polega na tym, że Jego dzieła dokonane w ciele były w pełni czynami Boga. Skoro Chrystus przyjął naturę ludzką, to należy ona do Osoby Słowa, chociaż dalej pozostaje doskonale ludzką. Przez ten akt wszystko, co ludzkie w Chrystusie, stało się absolutnie boskie. Jego myśli, działania i samo istnienie są myślami, działaniem $i$ istnieniem Osoby Boskiej, a więc objawiały nam Jego wolę, która jest tożsama z Jego istotą. Jest to logiczna konsekwencja podwójnej relacji, jaka istniała w Chrystusie. Logos poprzez Wcielenie doskonale złączył się hipostatycznie z naturą ludzką, a mimo to cały czas przebywał na łonie Ojca. Dusza Chrystusa cieszyła się niezakłóconym i uszczęśliwiającym wyczuciem zarówno Boga, jak i swojej z Nim jedności. Wszystko, co należało do Ojca, było też Jego własnością ${ }^{14}$.

Zatem kiedy Jezus działał w swoim ziemskim życiu, to każde najmniejsze ludzkie działanie było objawieniem misterium $0 j \mathrm{ja}^{15}$ oraz misterium Trójcy. Charakter zjednoczenia hipostatycznego sprawia bowiem, że com-

10 Por. J. J. Pelikan, Duch wschodniego chrześcijaństwa..., dz.cyt., s. 105.

11 Por. J. J. Pelikan, Duch wschodniego chrześcijaństwa..., dz. cyt., s. 76-93.

12 Por. J. Corbon, Liturgia - źródło wody życia, tłum. A. Foltańska, Poznań 2005, s. 39.

13 Por. J. J. Pelikan, Duch wschodniego chrześcijaństwa..., dz. cyt., s. 91.

14 Por. J. P. Strumiłowski, Zrodzony z wiary. Teologiczne podstawy tożsamości człowieka według Thomasa Mertona, Kraków 2016, s. 55-56.

15 Por. J. Corbon, Liturgia - źródło wody życia..., dz. cyt., s. 39. 
municatio idiomatum, które jest formą orzekania własności obu natur przynależnych jednemu podmiotowi, oznacza także, że na podstawie owego zjednoczenia możemy powiedzieć, że jedna natura wyraża się poprzez drugą, co stanowi o epifanijności faktu wcielenia. Zależność ta jest ewidentna w przypadku przymiotów właściwym obu naturom (ludzka wola w pełni wyrażała Boską), natomiast w przypadku przymiotów rozbieżnych rodzi się pewnego rodzaju wątpliwość.

Wskazana powyżej zależność współorzekania przymiotów rodzi zatem pewne problemy, gdyż oczywistym faktem jest, że Boska natura nie może ulegać zmianie w czasie lub w jakikolwiek sposób być zachwiana, na przykład poprzez cierpienie ludzkiej natury Chrystusa, natomiast ludzka natura Zbawiciela nie może przyjąć przymiotów natury boskiej ${ }^{16}$, a mimo to charakter zjednoczenia hipostatycznego według orzeczenia chalcedońskiego nie zakłada rozdziału. Jednakże według wstępnych ustaleń natura communicatio idiomatum nomen omen świadczy przecież o współorzekaniu, co powinno prowadzić do wydobycia prawdy, że ludzkie czyny Chrystusa są objawieniem boskiej rzeczywistości. Zatem w świetle tych rozważań, możemy powiedzieć, że chociaż natura boska nie podlega cierpieniu i że Chrystus cierpiał w swojej ludzkiej naturze lub że Syn cierpiał w ciele, to jednak cierpienie owo objawiało coś z istoty Boga ${ }^{17}$. Niniejszy artykuł stanowi próbę odczytania w perspektywie zasady o współorzekaniu przymiotów, rozumianej integralnie z jej chrystologicznym uzasadnieniem sformułowanym na soborze w Chalcedonie, epifanijnego znaczenia zbawczego cierpienia zainaugurowanego wkroczeniem Chrystusa do ogrodu Getsemani.

\section{Problem cierpienia Boga}

Religijny wymiar cierpienia w chrześcijaństwie jest nierozerwalnie sprzężony z odkupieńczym cierpieniem Chrystusa. Zazwyczaj mówiąc

16 Por. J. J. Pelikan, Powstanie wspólnej tradycji (100-600), tłum. M. Höffner, Kraków 2008, S. 239.

17 Por. J. Corbon, Liturgia - źródło wody życia..., dz. cyt., s. 39. 
o cierpieniu odczytywanym w kluczu chrześcijańskiej antropologii, zwraca się uwagę na fakt, że jest ono z jednej strony związane z naturą psychofizyczną podlegającą zniszczeniu, a z drugiej (spoglądając z teologicznego punktu widzenia) z odpowiedzialnością za grzech. Odkupieńcze znaczenie cierpienia natomiast wiązane jest z faktem wejścia w tę trudną egzystencjalną przestrzeń Boga w akcie wcielenia, przez co może ono być miejscem spotkania z Nim. Po wtóre zwraca się uwagę, że z tego względu, iż cierpienie w Chrystusie przestaje być przestrzenią obcą Bogu, wiąże się ono z miłością i ma moc wyzwalania miłości, która może przekroczyć cierpienie. Cierpienie zatem może prowadzić do przekraczania siebie ku innemu ${ }^{18}$. W tym miejscu warto zwrócić uwagę, że owo soteriologiczne znaczenie cierpienia pojmowane jest na płaszczyźnie psychologiczno-egzystencjalnej jako przekroczenie własnej ograniczoności w konfrontacji z cierpieniem (człowiek cierpiący lub doświadczający cierpienia bliskich może przestać skupiać się na sobie). Oczywiście owo wyzwalające znaczenie cierpienia nie jest samoistnym jego skutkiem, ale owocem towarzyszącej cierpieniu miłości, co z teologicznego punktu widzenia jest związane z wejściem Syna Bożego w przestrzeń cierpienia. Z tego też wynika fakt przekroczenia cierpienia i śmierci w kierunku życia wiecznego - co dzieje się w przypadku przeżywania cierpienia w zjednoczeniu z cierpiącym Chrystusem. Niemniej w takiej perspektywie cierpienie samo w sobie nie zawiera żadnego elementu zbawczego lub teologicznego, ale fakt współistnienia miłości z cierpieniem dopiero taki element wyzwala. Zatem cierpienie Chrystusa w takiej perspektywie nadal jawi się jako przyjęte, lecz niewyrażające (nieobjawiające) nic z istoty Boga. To raczej miłość jest tym elementem, który poprzez cierpienie (a nawet pomimo cierpienia) przybliża nam Boga. Cierpienie natomiast jest tylko tłem (okazją) do Jego objawienia.

Tego typu myślenie jest zgodne z tradycyjnym rozumieniem niecierpiętliwości Boga oraz z przypisywaniem przymiotów konkretnym naturom w Chrystusie. Zauważamy tutaj bowiem podobny schemat. W jednej rzeczywistości (w wydarzeniu Jezusa) spotyka się cierpienie, które przy-

18 Por. J. Zabielski, Eschatologiczny wymiar ludzkiego cierpienia i śmierci, „Rocznik Teologii Katolickiej” 12 (2013) nr 2, s. 219-230. 
jął On, przyjmując ludzką naturę ${ }^{19}$, ale samo sterylne koegzystowanie obok siebie ludzkiego cierpienia i boskiej miłości może sugerować brak konsekwentnego połączenia w myśl orzeczenia Soboru Chalcedońskiego. Z jednej strony bowiem cierpienie, co prawda przyjęte, nie zostało przebóstwione ani też Boska natura Syna nie uległa cierpieniu, co stanowi zadośćuczynienie orzeczeniu chalcedońskiemu o zjednoczeniu „bez zmieszania i bez zmiany" ${ }^{20}$, z drugiej jednak strony taka narracja sugeruje, jakoby obie rzeczywistości, przenikając się (Boska miłość wypełnia przestrzeń cierpienia), pozostawały mimo wszystko sterylne, co może godzić w samą istotę zjednoczenia hipostatycznego, poprzez redukcję lub pominięcie dwóch kolejnych orzeczników chalcedońskich, jakimi są: „bez podzielenia i bez rozłączenia”"21. Innymi słowy w takim schemacie nie widać, w jaki sposób cierpienie (lub chociaż jego potencjalność) staje się słowem objawiającym Boga. Natomiast taka intuicja, według której cierpienie może wyrażać coś z natury Boga, ma mocne uzasadnienie.

Otóż tezę taką zdają się potwierdzać już teksty starotestamentowe, które zawierają w sobie echo świadectwa o pojmowaniu Boga jako w pewnym sensie współcierpiącego i pełnego empatii względem człowieka. Tradycja rabiniczna w tekstach biblijnych ukazujących konsekwentne towarzyszenie Boga człowiekowi uwikłanemu w cierpienie i grzech dostrzegała ślad prawdy o boskim współcierpieniu. Podobnie odczytywane w tejże tradycji jest cierpienie proroków, którzy są reprezentantami Boga. Rozumienie owej reprezentacji może nieść za sobą pewnego rodzaju formę ukazania cierpienia samego Boga ${ }^{22}$.

Tradycja wczesnochrześcijańska dokonała oczywiście reinterpretacji tych wszystkich miejsc objawienia „Boskiej pasji” w kluczu chrysto-

19 Samo cierpienie jako stan nie jest czymś przynależącym do natury ludzkiej. Inaczej bowiem człowiek musiałby cierpieć z konieczności. Do natury ludzkiej należy jednak potencjalność cierpienia, co wynika z przygodności człowieka. Syn, wcielając się, przyjął naturę ludzką - czyli przyjął naturę potencjalnie zdolną do cierpienia, a odkupieńczy charakter tegoż wcielenia implikował przyjęcie konsekwencji grzechu, wśród których jest cierpienie.

20 Por. Sobór Chalcedoński, Definicja wiary, dz. cyt., 11.

21 Por. Sobór Chalcedoński, Definicja wiary, dz. cyt., 11.

22 Por. G. Greshake, Dlaczego Bóg pozwala nam cierpieć?, tłum. M. Szczepaniak, Kielce 2008, s. $83-86$. 
logicznym. Ojcowie Kościoła, czytając Stary Testament, tłumaczą, że to Chrystus cierpiał w Adamie, Hiobie, prorokach itp ${ }^{23}$.

Owa reinterpretacja starotestamentowych przesłanek w duchu analogii i prefiguracji pozwala jednak spojrzeć na niecierpiętliwość Boga w sposób mniej radykalny, niż mogłoby to wynikać z wizji filozoficznego Absolutu, na co wskazuje Joseph Ratzinger:

Starożytny świat grecki wskazał na niezmienność Boga, a tym samym ukazał Go również jako czystego ducha, który nie może odczuwać, a tym bardziej cierpieć. Chrześcijan wizja ta skłoniła do pytania, jak rzeczywiście wygląda sprawa z Bogiem. Orygenes pięknie powiedział kiedyś: Bóg nie może co prawda cierpieć, ale może współ-cierpieć. To znaczy: może się utożsamiać z nami, cierpiącymi. Identyfikacja ta jest wielkim aktem miłości, w której Bóg w Jezusie utożsamia się z nami aż po sferę cielesności - a tym samym utożsamia nas z Nim i wciąga w Jego miłośćc ${ }^{4}$.

Co więcej, konsekwentne odczytywanie historii zbawienia w kontekście wkraczania Boga w ludzkie cierpienie może rodzić przeświadczenie o odwiecznej świadomości przez Boga przyszłego upadku świata - jeszcze przed jego stworzeniem ${ }^{25}$, $\mathrm{z}$ apriorycznym postanowieniem zbawienia świata poprzez wkroczenie w przestrzeń jego cierpienia oraz wypełnienie tejże przestrzeni swoją miłością i obecnością ${ }^{26}$. Zatem wydawać

23 Por. H. de Lubac, Katolicyzm: społeczne aspekty dogmatu, tłum. M. Stokowska, Por. H. de Lubac, Katolicyzm: społeczne aspekty dogmatu, tłum. M. Stokowska, Wydawnictwo Znak, Kraków 1961, s. 182.

${ }^{24}$ J. Ratzinger, P. Seewald, Bóg i świat: wiara i życie w dzisiejszych czasach, tłum. G. Sowinski, Kraków 2001, s. 179-180.

25 Dowodzi tego chociażby tekst Pierwszego listu św. Piotra: „On był wprawdzie przewidziany przed stworzeniem świata, dopiero jednak w ostatnich czasach się objawił ze względu na was" (1 P, 1, 20). Zależność tę poświadcza również tekst Ap 13, 8. Polski przekład Biblii Tysiąclecia tłumaczy ów fragment w następujący sposób: „Wszyscy mieszkańcy ziemi będą oddawać pokłon władcy, każdy, którego imię nie jest zapisane od założenia świata w księdze życia zabitego Baranka" [podkr. J.P. S.], natomiast tekst oryginal-

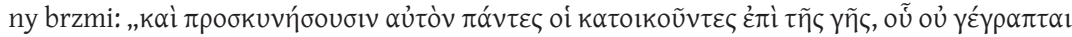

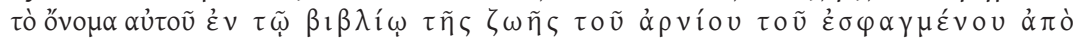
$\kappa \alpha \tau \alpha \beta \circ \lambda \tilde{\eta} \varsigma \kappa o ́ \sigma \mu \circ v^{\prime \prime}[$ podkr. J. P. S.], co można również przetłumaczyć słowami (chodzi o tekst rozstrzelony): „w zwoju życia Baranka zabitego od założenia świata", czego oczywiście nie trzeba interpretować w znaczeniu chronologicznym, ale istotowym, a co pozostaje w zgodzie z cytowanym tekstem 1 P $1,20$.

26 Por. G. Greshake, Dlaczego Bóg pozwala nam cierpieć?, dz. cyt., s. 84-86. 
by się mogło, że wszystko pozostaje tutaj w zgodzie ze wskazaną narracją o równoległym i niekolizyjnym spotkaniu cierpienia z miłością w Chrystusie. Jednakże aprioryczność aktu zbawienia, która jest pochodną prawdy o niezmienności Boga ${ }^{27}$, w logicznej konsekwencji zdaje się potwierdzać, że odwiecznie w Bogu musiał istnieć jakiś boski substytut, mogący być wyrażony w ludzkim cierpieniu mającego się wcielić Logosu.

Samo cierpienie, lub raczej możliwość podlegania cierpieniu, wynika ze stworzonej (przygodnej) natury człowieka. W tym też właśnie sensie stworzenie pozostaje radykalnie inne od natury boskiej. Jednakże stworzenie, jako chciane, jest także pewnego rodzaju medium objawienia Boga, odsłaniającym nam pewne aspekty boskiego życia ${ }^{28}$. Świat w takiej perspektywie jawi się w swojej całości jako miejsce objawienia Boga, jako pewnego rodzaju Jego czasoprzestrzenny obraz ${ }^{29}$. Chrystus w tej perspektywie w swojej ludzkiej naturze w sposób doskonały jest objawieniem Boga, gdyż w jego ludzkiej naturze podobieństwo sięga szczytu. Niemniej, jak się okazuje, szczytem objawienia jest samo wydarzenie krzyża, co sugeruje, że cierpienie niesie w sobie ogromny ładunek epifanijny ${ }^{30}$.

$\mathrm{Z}$ drugiej jednak strony cierpienie jest związane z grzechem pierworodnym, jest jego skutkiem ${ }^{31}$. Te dwie zależności wydają się zatem stanowić poważną sprzeczność, gdyż ukazują one w jednej perspektywie stworzenie, które jest medium objawienia rzeczywistości boskiej, i stworzenie, którego cierpienie jest skutkiem grzechu. Zestawienie tych dwóch zależności wydaje się sugerować, jakoby grzech miał swoje miejsce w naturze samego Boga, co jest w najwyższym stopniu nie do przyjęcia.

Warto jednak zwrócić uwagę na pozorność tej sprzeczności, poprzez dostrzeżenie drobnej, aczkolwiek istotnej dystynkcji. Natura stworzona przez Boga nie jest naturą cierpiącą, ale naturą, która jest zdolna do cier-

${ }_{27}$ Por. J. D. Szczurek, Trójjedyny: traktat o Bogu w Trójcy Świętej jedynym, Kraków 2003, s. 250.

28 Por. R. J. Woźniak, Materialno-biologiczny wymiar obrazu Bożego w człowieku, „Scientia et Fides" 2 (2014) nr 2, s. 286.

${ }_{29}$ Por. M. Seckler, Zbawienie w historii: teologia historii w nauce świętego Tomasza z Akwinu, tłum. W. Szymona, Kraków 2015, s. 105-115.

30 Por. J. Galot, Dieu souffre-t-il?, éd. P. Lethielleux, Paris 1976, s. 11.

31 Por. Jan Paweł II, list apost. Salvifici dolores. 
pienia. Samo cierpienie jest natomiast skutkiem grzechu, czyli odłączeniem się od Boga, który jest pełnią szczęścia.

Dystynkcja ta wydaje się otwierać przed nami możliwość odczytania cierpienia Chrystusa - zwłaszcza w momencie szczytowym, jaki stanowiła agonia w Ogrójcu i na krzyżu, w świetle communicatio idiomatum, w jego epifanijej funkcji.

\section{Ogrójec jako wejście Chrystusa w sferę nieznaną}

Zagadnienie, jakie wyłania się z powyższych rozważań, skupia zatem w sobie kilka aspektów. Na zasadzie współorzekania przymiotów trzeba nam określić, w jaki sposób cierpienie Jezusa objawiało Boga i co z rzeczywistości boskiej mogło ono objawiać. Po drugie należy pamiętać o soteriologicznym znaczeniu cierpienia Chrystusa, gdyż w ziemskim życiu Syna Bożego aspekt epifanijny i soteriologiczny są nierozdzielnie splecione. Należy zatem w cierpieniu Jezusa odnaleźć taką przestrzeń, która zgodna będzie z Jego dziełem zbawienia i zarazem wyrażała będzie jakąś prawdę o wewnętrznym życiu samego Boga, co wydaje się możliwe przy wieloaspektowym odczytaniem faktu konania w Ogrójcu ${ }^{32}$.

Już najstarsza tradycja, wyrażona w komentarzach ojców Kościoła do Ewangelii, świadczy, że samo miejsce konania, czyli „ogród”, rozumiane było na sposób typologiczny, wskazując na odniesienie do ogrodu rajskiego $^{33}$. Święty Tomasz z Akwinu, komentując te intuicje ojców, stwierdza, że tak rozumiane miejsce jest jak najbardziej właściwe dla początku dzieła

32 Ściśle rzecz ujmując, termin communicatio idiomatum dotyczy dwóch sfer: 1) języka wyznaczając poprawne teologicznie zasady orzekania o Chrystusie, które są zgodne ze sferą; 2) metafizyczną - odnoszącą się do samej „rzeczywistości” Chrystusa, w którym dwie natury są zjednoczone hipostatycznie (por. G. Strzelczyk, Communicatio idiomatum. Propozycja systematyzacji, dz. cyt., s. 297-298). W tym artykule, analizując wydarzenie konania w Ogrójcu, nie odnoszę się ściśle do konkretnego sformułowania, czyli nie stosuję communicatio idiomatum w znaczeniu klasycznym. Niemniej jednak odnoszę się do sfery ontologicznej tejże zasady, dla zinterpretowania wydarzenia, które jest pewnego rodzaju „wyrażeniem” ufundowanym na ontologicznej strukturze zasady o współorzekaniu przymiotów.

33 Por. S. Mędala, Ewangelia według świętego Jana, cz. 2:Rozdziały 13-21, Częstochowa 2010, s. 182 (Nowy Komentarz Biblijny. Nowy Testament, 4). 
odkupienia, gdyż w ten sposób Jezus, by odkupić świat, wkracza na miejsce, w którym grzech się dokonał ${ }^{34}$. Takie ujęcie tłumaczy mocną centralizację modlitwy Jezusa na posłuszeństwie Ojcu ${ }^{35}$. Pierwszy grzech, dokonany w raju, był nieposłuszeństwem względem woli Boga. Jezus wkracza na to samo miejsce (można powiedzieć, że wkracza jeszcze raz w przestrzeń wolności walczącej o posłuszeństwo Ojcu), by jeszcze raz w imieniu człowieka dokonać aktu posłuszeństwa, który byłby odwrotnością nieposłuszeństwa Adama. Zwłaszcza Ewangelia według Mateusza zdaje się potwierdzać taką zależność, podkreślając różnicę między nieposłuszeństwem (upadkiem) uczniów, którzy wszak są synami Adama, oraz doskonałym posłuszeństwem Jezusa, które jest źródłem zbawienia ${ }^{36}$.

Kontekst ponawianego wyboru jest jednak radykalnie inny. Adam w raju cieszył się przyjaźnią i bliskością Boga. Jezus natomiast, przychodząc do ogrodu Oliwnego, wkracza w przestrzeń zdeformowaną grzechem, co sugeruje sam opis owego ogrodu pogrążonego w ciemności. Aspekt ten podkreśla również ewangelista Łukasz, który w taki sposób komponuje samą scenę konania Jezusa w Ogrójcu, by podkreślić Jego wewnętrzną walkę o nieuleganie słabości ludzkiej natury w obliczu ekstremalnego przeżycia strachu ${ }^{37}$.

Zauważyć w tym miejscu możemy, że cierpienie Jezusa - tutaj głównie cierpienie duchowe, które jest bardziej fundamentalne i podstawowe niż cierpienie fizyczne - jest związane z wkroczeniem Syna Bożego w egzystencjalną przestrzeń skutków grzechu. Wejście w taką przestrzeń nie jest niczym innym, jak wkroczeniem w przestrzeń potencjalnej utraty obecności Boga, odczuciem i realnym doświadczeniem rzeczywistości skutku grzechu, jakim jest potępienie (oddalenie od Boga) ${ }^{38}$. Tak radykalne doświadczenie przez Jezusa kondycji człowieka upadłego, które

${ }^{34}$ Por. Tomasz z Akwinu, Komentarz do Ewangelii Jana, tłum. T. Bartoś, Antyk, Kęty 2002, S. 1057.

35 Por. A. Paciorek, Ewangelia wedtug świętego Mateusza, cz. 2: Rozdziały 14-28, Częstochowa 2008, s. 575 (Nowy Komentarz Biblijny. Nowy Testament, 1).

${ }^{36}$ A. Paciorek, Ewangelia według świętego Mateusza, cz. 2: Rozdziały14-28, dz. cyt., s. 775-776.

37 Por. F. Mickiewicz, Ewangelia według świętego Eukasza, cz. 2: Rozdziały 12-24, Częstochowa 2012, s. 478-479 (Nowy Komentarz Biblijny. Nowy Testament, 3).

${ }_{38}$ Por. H. U. von Balthasar, Teologia misterium paschalnego, tłum. E. Piotrowski, Kraków 2001, s. 93-96. 
sięga „noszenia-w-sobie” winy wszystkich, jest możliwe właśnie dzięki unii hipostatycznej ${ }^{39}$. W tej perspektywie lęk Ogrójca jest, jak pisze Hans Urs von Balthasar,

takim współ-cierpieniem z grzesznikami, iż realna możliwość utraty Boga (poena damni) stojąca przed nimi zostaje przyjęta przez wcieloną miłość Boga w postaci „timor gehennalis”: aby grzech świata mógł zostać „włożony” na Jezusa, nie odróżnia On już siebie i swego losu od losu grzeszników ${ }^{40}$.

W takiej perspektywie istotą cierpienia Jezusa wydaje się wkroczenie w przestrzeń zupełnie nieznaną Synowi Bożemu, tzn. w przestrzeń egzystencjalną grzesznika, która jest doświadczeniem lęku aż do śmierci oraz całkowitego i ostatecznego opuszczenia przez Boga, co właśnie oznacza doświadczenie istoty grzechu ${ }^{41}$. Jezus cierpi w Ogrójcu, bojąc się tego, co jest mu całkowicie obce - cierpi, doświadczając tego, co jest obce Bogu, a to cierpienie konsekwentnie ogarnia całą Jego egzystencję. Obcość, której treścią jest grzech, dotyka każdej sfery Jego istnienia, powodując cierpienie duchowe, psychiczne i cielesne. Przestrzeń grzechu jest jedyną przestrzenią, której Bóg nie zna. Wkraczając do Ogrójca, Jezus wkracza zatem w przestrzeń, która nie mieści się w granicach boskiej istoty. Lęk Jezusa, jako skutek wkroczenia w tę wrogą Bogu przestrzeń, jest więc poczuciem destabilizacji i rozbicia wszystkiego, co do tej pory w Jego boskiej naturze było mu znane.

Nie ulega wątpliwości, że grzech jest rzeczywistością nieznaną Bogu (w znaczeniu poznania doświadczalnego). Dookreślić tutaj należy, że Jezus bezpośrednio w przestrzeń grzechu nie wkracza, gdyż chociaż przyjął grzechy ludzkości, to sam grzechu nie popełnił. Poprzez fakt wkroczenia w kondycję grzesznika doświadcza jednak skutków grzechu, które również dla Boga są rzeczywistością obcą. To doświadczenie konkretyzuje się i jest źródłem Jego cierpienia. Pytanie zasadnicze, które rodzi się w tym kontekście, nabiera zatem innego odcienia. Zapytać należy więc,

\footnotetext{
39 Por. H. U. von Balthasar, Teologia misterium paschalnego, dz. cyt., s. 94.

40 Por. H. U. von Balthasar, Teologia misterium paschalnego, dz. cyt., s. 97.

${ }_{41}$ Por. H. U. von Balthasar, Czy Jezus nas zna? Czy my znamy Jezusa?, tłum. E. Piotrowski, Kraków 1998, s. 23-26.
} 
co z rzeczywistości Boskiej objawia nam owo doświadczenie cierpienia? Skoro nie może objawiać wewnątrzboskiego cierpienia (gdyż takie nie istnieje), to czy może objawiać nam pewien mechanizm pełnego „trwogi” wkraczania Boga w przestrzeń „nieznaną” lub czy w rzeczywistości wewnątrztrynitarnej istnieje pewna „matryca” wkraczania w to, co nieznane, co mogłoby być objawione w wejściu Chrystusa w przestrzeń skutków grzechu, rozumianego jako oddalenie od Boga?

\section{Doświadczenie dystansu w Bogu}

Odnalezienie elementu wkraczania w „przestrzeń nieznaną”, który dostrzegliśmy w akcie wkroczenia Chrystusa do Ogrójca inaugurującym Jego zbawczą mękę, dostrzec możemy również w teologicznej prawdzie o stworzeniu świata ex nihilo.

Stworzenie świata „z niczego” w pierwszym rzędzie wyraża całkowitą odmienność świata względem natury boskiej. Olivier Clement, wyjaśniając tę prawdę, poddaje analizie zaczerpnięte z Septuaginty słowa „oủk દ̇ względnego w sensie pierwotnym, gdyż względem Boga nie istnieje żadna sfera „nicości”, ale jest to pojęcie graniczne, wskazujące, że Bóg spra-

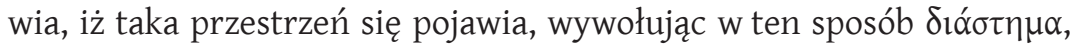
co oznacza, że w akcie stwórczym Bóg w pewnym sensie tworzy dystans względem swojej pełni rozumiany nie przestrzennie, ale w sensie natury. W ten sposób w akcie stwórczym Bóg dopuszcza powstanie rzeczywistości całkowicie odmiennej ${ }^{42}$. Dopiero w tej przestrzeni Bóg powołuje świat do istnienia, czyli wypełnia tę przestrzeń cząstką swojego istnienia, z czego logicznie wynika, że stworzenie jest radykalnie inne od Stwórcy, ale jednocześnie jest wyrazem Jego istoty. Ponadto w tak rozumianym akcie stwórczym Bóg, by wypełnić ową „przestrzeń” nieistnienia, wykracza w pewnym sensie poza siebie, albo raczej patrząc z innej perspektywy, wkracza właśnie w przestrzeń sobie nieznaną (przestrzeń nieistnienia).

${ }_{42}$ Por. O. Clément, Boski kosmos: wybrane zagadnienia z kosmologii, tłum. P. Mikulska, Kraków 2010, s. 12. 
Opis ten jednak nie jest jeszcze w pełni satysfakcjonujący w aspekcie epifanijnym, gdyż wskazuje on na zasadniczą zgodność i przystawalność aktu stworzenia z aktem odkupienia. Oba zawierają w sobie element wkraczania w przestrzeń nieznaną. Niemniej akt stworzenia sam w sobie jest już dziełem epifanijnym, tzn. jest wyrazem i uzewnętrznieniem wewnątrztrynitarnego życia Boga, lecz nie stanowi opisu rzeczywistości źródłowej względem objawienia. Dalej zatem nie wiemy, czy w samym Bogu istnieje proces wkraczania w to, co nieznane, którego wyżej wskazana interpretacja stworzenia i odkupienia są analogatami.

Aby źródło takiej analogiczności odnaleźć, należy wejść na obszar teo-ontologii, próbując w jej obrębie odnaleźć źródło realizacji wskazanego postulatu rozpoznanego w akcie stworzenia i odkupienia. Możliwość takiego poszukiwania wydaje się stwarzać głębsza, teo-ontologiczna analiza koncepcji stworzenia człowieka z miłości (ex amore ${ }^{43}$ ), którą należy rozumieć integralnie względem formuły stworzenia ex nihilo. Perspektywa stworzenia z miłości odnosi nas bowiem do samej istoty Boga. Zatem pytanie, które nieustannie zadajemy na kartach niniejszego artykułu, przybiera jeszcze precyzyjniejszą formę, stając się pytaniem o rozumienie miłości, która jest tożsama z Bogiem, a dokładniej o to, czy w Bogu-miłości możemy dostrzec aspekt pełnego trwogi przekraczania własnej granicy ku temu, co nieznane i naznaczone egzystencjalnym brakiem?

Teo-ontologiczny opis miłości w aspekcie trynitarnym spontanicznie skupia się na wektorze ekspansji i obdarowywania, czyli na tym jej aspekcie, który jest zawarty w greckim terminie agape. Jest to miłość, która jest nieustannym obdarowywaniem. W aspekcie trynitarnym miłość w ten sposób rozumiana stanowi podstawę modelu wewnątrzboskiej ekonomii. Według takiego modelu życie wewnątrztrynitarne jest nieustannym obdarowywaniem, oddawaniem własnej istoty na rzecz drugiego „Ty”. W ten sposób Ojciec rodzi Syna z własnej istoty - obdarowując Go własnym istnieniem. Syn natomiast, rozpoznając ów dar, całe swoje istnienie oddaje Ojcu. To wzajemne obdarowywanie o charakterze istotowym

43 Por. Z. Kijas, Początki świata i człowieka, Kraków 2004, s. 280-300; Sobór Watykański II, konst. Gaudium et spes, 19. 
jest Duchem Świętym - wzajemnym miłosnym oddaniem ${ }^{44}$. Oczywiście takie ujęcie zakłada już współistnienie tego wektora miłości, który określamy mianem eros, gdyż w życiu wewnątrztrynitarnym mamy do czynienia nie tylko z obdarowywaniem, ale także z przyjmowaniem, co identyfikowane jest z tym właśnie aspektem miłości ${ }^{45}$. Uświadamia to nam tradycyjnie pojmowaną (obecną już u ojców) tożsamość dwóch wymiarów miłości: agape i $\operatorname{eros}^{46}$.

Tak zbudowany model, mimo że stara się realizować zgodne współistnienie dwóch wymiarów miłości, które dopiero czynią ją pełną ${ }^{47}$, wydaje się jednak nie dość wyraźnie eksponować wymiar eros, którego pełne dowartościowanie może nieść ze sobą potencjał ukazywania tego aspektu życia wewnątrztrynitarnego, który jest wyrażany w wyżej wskazanym akcie stwórczym oraz, co najważniejsze, w soteriologicznym akcie przekraczania granic boskiej istoty ${ }^{48}$. Znaczenie greckiego słowa eros, które w kontekście trynitarnym trudno jest poddać „destylacji” oddzielającej je od znaczenia agape, w wydźwięku teologicznym najczęściej jest rozumiane jako „porwanie” ludzkiego ducha w stronę tego, co prawdziwe, dobre i piękne ${ }^{49}$, lub jako „upojenie, opanowanie rozumu przez «boskie szaleństwo», które wyrywa człowieka z ograniczoności jego istnienia i w tym stanie wstrząśnięcia przez boską moc pozwala mu doświadczyć najwyższej błogości”50. Niemniej jednak samo słowo eros niesie w sobie także znaczenie przekraczania granicy, tęsknego poszukiwania, dążenia do

${ }^{44}$ Por. B. Grzegorz, Miłość Boga w ujęciu J. Razingera/Benedykta XVI, „Verbum Vitae” 23 (2013), s. 255.

45 Por. B. Grzegorz, Miłość Boga w ujęciu J. Razingera/Benedykta XVI, dz.cyt., s. 255.

46 Por. J. P. Strumiłowski, Piękno zbawi świat?, Kraków 2016, s. 183.

47 Por. Benedykt XVI, enc. Deus caritas est, 7.

${ }_{48}$ Rzecz jasnajuż samo ukazanie wymiaru agape w jakiś sposób tłumaczy przekraczanie granic własnego istnienia. Agape w aspekcie stwórczym jest wylaniem i udzieleniem własnego istnienia stworzeniu (creatio ex nihilo). Niemniej jest to pełna pozytywnej afirmacji ekspansja, przekraczające własne granice. W takim radosnym wypełnianiu nowych przestrzeni wydaje się nie mieścić przekraczanie granicy w kierunku przestrzeni grzechu, co musi wiązać się nie tylko z pozytywnym rozlaniem miłości, ale także z pełnym trwogi istotowym wkroczeniem w przestrzeń sprzeczną z tymże wkraczającym istnieniem.

49 Por. Jan Paweł II, Mężczyzna i niewiastą stworzył ich: Odkupienie ciała a sakramentalność małżeństwa, Città del Vaticano 1986, s. 191.

50 Por. Benedykt XVI, enc. Deus caritas est, 4. 
zjednoczenia jeszcze niedokonanego, na co wskazuje papież Benedykt XVI w encyklice Deus Caritas est przy okazji omawiania tego rodzaju miłości w aspekcie antropologicznym ${ }^{51}$. Eros oznacza zatem także tęsknotę i poszukiwanie tego, co jeszcze nie jest w pełni zrealizowane.

Aplikując to znaczenie do ontologii trynitarnej, daje się dostrzec głębszy wymiar miłości, pozwalający doprecyzować, że owo wzajemne obdarowywanie własną istotą Syna przez Ojca i Ojca przez Syna w Duchu Świętym nie jest jedynie formą radosnego dzielenia się sobą, oddawania własnej istoty w czystym darze, ale w tym oddawaniu istnieje pierwiastek pełnej troski tęsknoty za pełnym istnieniem „Drugiego”. Ojciec rodzi Syna, udzielając mu daru z własnego istnienia (rodzi Go z własnej substancji) nie tylko w akcie pozytywnego daru, ale też z przepełnionej szaloną tęsknotą miłością za Synem, z pełnego pasji pragnienia, aby On był!

W aspekcie stwórczym prawda ta dookreśla koncepcję creatio ex amore w takim sensie, że stworzenie przestaje jawić się jedynie jako afirmacja boskiej istoty „poza Nim” (w nie-Bogu), czyli pobudką stworzenia nie była tylko epifania boskiej chwały i dzielenie się nią, ale pewnego rodzaju odwieczna tęsknota za jeszcze nieistniejącym lub nieistniejącym jeszcze w pełni człowiekiem. W takim sensie Bóg w akcie stwórczym przekroczył swoją istotą granicę nieistnienia (creatio ex nihilo), z obawy nieistnienia człowieka i z nieskończonej tęsknoty za jego istnieniem. Człowiek w takiej perspektywie, chociaż nie istnieje odwiecznie, to odwiecznie jest przez Boga kochany, a ta miłość złączona z pełną trwogi tęsknotą prowokuje Boga do wejścia w przestrzeń nieistnienia (gdzie w sensie metafizycznym przed stworzeniem - mówiąc obrazowo - znajdował się człowiek), by człowieka z nieistnienia wydobyć.

$\mathrm{W}$ takiej perspektywie akt wcielenia i odkupienia wpisuje się $\mathrm{w}$ ten sam ruch przekraczania granicy „nieistnienia” z obawy przed nieistnieniem ukochanego człowieka. Podnietą dla stworzenia świata, wcielenia i odkupienia jest zatem integralnie rozumiana miłość, która chce się dzielić własnym istnieniem, ale również drży z obawy przed wpadnięciem obiektu swojej miłości (człowieka) w nieistnienie - czy to przez samą naturę

51 Por. Benedykt XVI, enc. Deus caritas est, 11. 
(człowiek z natury sam nie ma istnienia w sobie), czy to poprzez grzech, który jest oddzieleniem się od Boga - źródła istnienia.

Akt stworzenia, jak i akt wcielenia i odkupienia w takiej perspektywie jawią się jako epifanijne, a prawda epifanijna o naturze Boga wyrażona przez te akty jest spójna - jest nią wewnątrztrynitarna miłość, która sprowadza się nie tylko do elementu pozytywnego obdarowywania „Drugiego”, ale także do pełnej troski tęsknoty i zabiegania o istnienie ukochanego „Drugiego”.

Trwoga Jezusa w Getsemani jawi się natomiast w takiej perspektywie jako ostateczny krok ku centrum zwielokrotnionej przestrzeni niebytu (ontologicznego, moralnego, duchowego itp.), objawiając tym samym nieskończoną i odwieczną miłość Boga oraz siłę tej miłości, która nie cofa się przed żadną granicą.

Ponadto miłość tak pojmowana (i tak objawiona!) wydaje się mieć bardziej ludzkie oblicze, tzn. tak zdefiniowana teo-ontologiczna miłość wewnątrztrynitarna lepiej koresponduje z bosko-ludzkim obliczem miłości objawionej w Jezusie.

Sam obraz tak rozumianej miłości wydaje się natomiast bardziej pełny, przez co także obraz Boga jawi się jako bardziej integralny. Bóg jest miłością, a miłość ta nie tylko ma radosne oblicze, ale zawiera się w niej także tęsknota oraz siła przełamująca granice ku temu, za czym tęskni.

\section{Podsumowanie}

Jak więc widać, możliwe jest odczytywanie całego życia Jezusa i każdego aspektu Jego istnienia w kontekście epifanijno-zbawczym, bez rezygnacji z żadnej z tych dwóch perspektyw, w świetle prawdy o współorzekaniu przymiotów. Communicatio idiomatum, a właściwie jej teologiczna funkcja ${ }^{52}$, która zawiera w sobie potencjał epifanijny, konsekwentnie stosowana jako meta-teologiczna zasada hermeneutyczna, pozwala z wydarzenia wcielenia ujmowanego całościowo, jak i z każdego momentu ziemskiej historii Jezusa wydobyć pewnego rodzaju objawieniową wypowiedź

52 Por. G. Strzelczyk, Communicatio idiomatum. Propozycja systematyzacji, dz.cyt., s. 300. 
Boga, która w „wyrazie” ludzkiego życia Zbawiciela opowiada o „znaczeniu" miłości wewnątrztrynitarnej.

Ponadto powyższa analiza pokazuje fundamentalne znaczenie dogmatu trynitarnego, który nie tylko opowiada o Bogu samym w sobie, ale jest matrycą zarówno objawienia, jak i stworzenia. Oznacza to w konsekwencji, że rzeczywistość stworzona nosi niezbywalne znamię podobieństwa do swojego Stwórcy, co sprawia, że sam świat jawi się jako medium poznania i kontemplacji Boga. Dogmat trynitarny natomiast jest narzędziem hermeneutycznym pozwalającym na odczytanie obrazu Boga odciśniętego na stworzeniu, co jest równoznaczne z inicjacją aktu kontemplacji Stwórcy w stworzeniu.

Podobieństwo to jest tak silnie determinowane wewnętrzną istotą Trójjedynego, że wydaje się nie istnieć taka przestrzeń w stworzeniu, która mogłaby się wyrwać spod dynamiki objawiania i działania miłości Bożej. Oznacza to, że miłość Boża, której owocem jest stworzenie i odkupienie, jest tak radykalna, że nie istnieje dla niej żadna granica - nawet granica grzechu, który jest zanegowaniem Boga. W perspektywie ludzkiego doświadczenia świadczy to o tym, że nie może istnieć taka ciemność, która byłaby dla Boga niedostępna.

Natomiast sam charakter partycypowania Bożej prawdy zdeponowanej w stworzeniu i objawionej w Chrystusie unaocznia, że problem z dostrzeżeniem miłości Boga w niektórych sferach ludzkiej egzystencji może wynikać z ograniczonej perspektywy poznawczej. Przekroczenie tej perspektywy prowadzi zaś do poznania i doświadczenia jeszcze głębszych pokładów i znaczeń miłości Bożej, która chociaż przekracza wszelką miłość ludzką, to jest z nią spójna. Miłość Boża nie jest więc wydestylowanym z ludzkiego doświadczenia braku, pełnym afirmacji obdarowywaniem, ale również jest naznaczona elementem tęsknoty i trwogi, które nie umniejszają jej siły, ale ją wzmagają i czynią bardziej wiarygodną.

Konsekwentne spojrzenie poprzez pryzmat ontologicznego znaczenia prawdy o współorzekaniu przymiotów na objawienie, jak i w ogóle na świat, pozwala w ten sposób odnaleźć zaskakującą spójność i harmonię, które właśnie w tej niebywałej zgodności objawiają pierwiastek odwiecznej i niepojętej Bożej miłości. 


\section{Summary}

\section{Epifanijne znaczenie konania Jezusa w Ogrójcu w świetle communicatio idiomatum}

Zjednoczenia hipostatyczne w Chrystusie charakteryzuje się tym, że w orzeczeniach chrystologicznych możemy właściwości obu natur przypisywaćjednej osobie wcielonego Słowa, przy świadomości odrębności każdej z nich, co czyni zadość określnikom chalcedońskim „,bez zmieszania i bez zmiany”. Charakter tegoż zjednoczenia zakłada jednak także, że w myśl dwóch pozostałych określników „bez podzielenia i bez rozłączenia”, owe natury tak ściśle do siebie „przylegają”, iż poprzezjedną naturę wyraża się druga (Bóstwo objawia się w człowieczeństwie), co jest warunkiem epifanijności faktu wcielenia. W świetle tych założeń w niniejszym artykule została podjęta próba odczytania wydarzenia cierpienia Jezusa w Ogrójcu w taki sposób, żeby nie przypisywać właściwości natury ludzkiej (cierpienie) naturze boskiej, ale żeby wydobyć z tego wydarzenia jego potencjał epifanijny, czyli odczytać, co cierpienie Jezusa w Ogrójcu może objawiać o naturze boskiej.

Słowa kluczowe: Chrystologia, objawienie, trynitologia, współorzekanie przymiotów, cierpienie

\section{The Epiphanial Meaning of Jesus' Agony in Gethsemane in the Light of the Communicatio Idiomatum}

The hypostatic union in Christ consists in that, in Christological statements, we may attribute the qualities of both natures to the unique person of the Incarnated Word, having in mind their distinctiveness, which corresponds with the Chalcedonian Definition: "unconfusedly, unchangeably". However, the character of this union assumes also that, given the other determiners: "indivisibly" and "inseparably", both natures adhere one to the other so closely, that through one nature the other is expressed (the divinity is revealed in humanity), which constitutes the condition of the epiphanial character of the incarnation. In the light of these assumptions the present article attempts to interpret the Jesus' agony in Gethsemane not by attributing the features of the human nature (suffering) to the divine one, but by extracting from this occurrence all its epiphanial potential. In other words, the point is to read what the Jesus' suffering in Gethsemane may reveal of his divine nature.

Keywords: Christology, Revelation, trinitology, communication of properties, suffering 


\section{Bibliografia}

Balthasar H. U. von, Teologia misterium paschalnego, tłum. E. Piotrowski, Kraków 2001. Benedykt XVI, Encyklika Deus caritas est.

Clément O., Boski kosmos: wybrane zagadnienia z kosmologii, tłum. P. Mikulska, Kraków 2010.

Corbon J., Liturgia - źródło wody życia, tłum. A. Foltańska, Poznań 2005.

Galot J., Dieu souffre-t-il?, éd. P. Lethielleux, Paris 1976.

Greshake G., Dlaczego Bóg pozwala nam cierpieć?, tłum. M. Szczepaniak, Kielce 2008.

Grzegorz B., Miłość Boga w ujęciu J. Razingera/Benedykta XVI, „Verbum Vitae” 23 (2013), s. 245-265.

Jan Paweł II, List apostolski Salvifici dolores.

Jan Paweł II, Mężczyzną i niewiastą stworzył ich: Odkupienie ciała a sakramentalność matżeństwa, Città del Vaticano 1986.

Kijas Z., Początki świata i człowieka, Kraków 2004.

Lubac H. de, Katolicyzm: społeczne aspekty dogmatu, tłum. M. Stokowska, Kraków 1961.

Mędala S., Ewangelia według świętego Jana, cz. 2: Rozdziały 13-21, Częstochowa 2010 (Nowy Komentarz Biblijny. Nowy Testament, 4).

Mickiewicz F., Ewangelia według świętego Eukasza, cz. 2: Rozdziały 12-24, Częstochowa 2012 (Nowy Komentarz Biblijny. Nowy Testament, 3).

Paciorek A., Ewangelia wedlug świętego Mateusza, cz. 2: Rozdziały 14-28, Częstochowa 2008 (Nowy Komentarz Biblijny. Nowy Testament, 1).

Pelikan J. J., Powstanie wspólnej tradycji (100-600), tłum. M. Höffner, Kraków 2008.

Pelikan J. J., Duch wschodniego chrześcijaństwa (600-1700), tłum. M. Piątek, Kraków 2009.

Ratzinger J., Seewald P., Bógi świat: wiarai życiew dzisiejszych czasach, tłum. G. Sowinski, Kraków 2001.

Seckler M., Zbawienie w historii: teologia historii w nauce świętego Tomasza z Akwinu, tłum. W. Szymona, Kraków 2015.

Sobór Chalcedoński, Definicja wiary, w: Dokumenty Soborów Powszechnych:tekst grecki, łaciński, polski, t. 1, red. A. Baron, H. Pietras, tłum. T. Wnętrzak, Kraków 2005, s. 214-225.

Sobór Watykański II, Konstytucja Gaudium et spes.

Strumiłowski J. P., Zrodzony z wiary. Teologiczne podstawy tożsamościczłowieka według Thomasa Mertona, Kraków 2016.

Strumiłowski J. P., Piękno zbawi świat?, Kraków 2016.

Strzelczyk G., Communicatio idiomatum. Propozycja systematyzacji, „Śląskie Studia Historyczno-Teologiczne" 43 (2010) nr 2, s. 290-301.

Szczurek J. D., Trójjedyny: traktat o Bogu w Trójcy Świętej jedynym, Kraków 2003.

Tomasz z Akwinu, Komentarz do Ewangelii Jana, tłum. T. Bartoś, Kęty 2002.

Woźniak R. J., Materialno-biologiczny wymiar obrazu Bożego w człowieku, „Scientia et Fides" 2 (2014) $\mathrm{nr}$ 2, s. 271-288.

Zabielski J., Eschatologiczny wymiar ludzkiego cierpienia i śmierci, „Rocznik Teologii Katolickiej" 12 (2013) nr 2, s. 219-230. 